See discussions, stats, and author profiles for this publication at: https://www.researchgate.net/publication/327548200

\title{
The Role of Ethics in Developing Professionalism Within the Global ICT Community.
}

Article in International Journal of Human Capital and Information Technology Professionals · October 2018 DOI: 10.4018/JHCITP.2018100104

CITATIONS

6 authors, including:

Clare Thornley

Clarity Research

31 PUBLICATIONS 292 CITATIONS

SEE PROFILE

Marian Carcary

National University of Ireland, Maynooth

53 PUBLICATIONS 695 CITATIONS

SEE PROFILE

Some of the authors of this publication are also working on these related projects:

Multi-disciplinary Knowledge View project

Project

Technology Management View project
4,442

2.7néad Murnane

National University of Ireland, Maynooth

19 PUBLICATIONS 30 CITATIONS

SEE PROFILE

Eileen Doherty

National University of Ireland, Maynooth

21 PUBLICATIONS 242 CITATIONS

SEE PROFILE 


\title{
The role of ethics in developing professionalism within the global ICT community.
}

\author{
Clare Thornley (Innovation Value Institute) \\ Clare.thornley@mu.ie \\ Sinéad Murnane (Innovation Value Institute) \\ Stephen McLaughlin (Heriot Watt University) \\ Marian Carcary (Innovation Value Institute) \\ Eileen Doherty (Innovation Value Institute) \\ Louise Veling (Innovation Value Institute)
}

Key words: Ethics, ICT professionalism, information ethics, codes of ethics, e-Skills, European Union, internationalisation, professional education.

\begin{abstract}
This paper reports on a series of research and policy development projects investigating the development of Information Communication Technology (ICT) as a profession with a specific focus on the role of ethics. It addresses three main issues: to what extent ethics contribute to the development of the professional identity of ICT practitioners; what practices and policies can promote the development of ICT ethics; how these practices and policies can usefully be coordinated internationally. Within the European policy framework, professional ethics is seen as one of the four pillars of ICT professionalism, the others being: competences; bodies of knowledge; education and training. A diverse range of international stakeholders were consulted over a period of four years. The challenges of agreeing on what it means to be an ICT Professional and the best way to develop and implement ethical frameworks in culturally and economically diverse regions are discussed. Findings include the need to: be sensitive to the cultural and economic factors of different regions; integrate work on ethics with other aspects of professionalism; and promote multiple types of engagement with professional ethics.
\end{abstract}

\section{Introduction}

$\mathrm{ICT}$, and the information it stores and manipulates, is increasingly critical to many services and activities and its failure or lack of optimum performance can have very significant consequences (Sherry, Carcary, McLaughlin, \& O'Brien, 2013). There are many reasons for IT failures and some of them will have an ethical dimension either through malicious intent

Thornley, C., Murnane, S., McLaughlin, S., Carcary, M., Doherty, E., and Veling, L. 2018. International Journal of Human Capital and Information Technology Professionals (IJHCITP). 2018 9(4) :56-71. 
through hacking, or as an inadvertent effect caused by failure to adequately protect IT systems or develop robust enough systems. The role of human behaviour is often key either at the design phase, or in how ICT systems are used or delivered. Recent work on the role of corruption as a source of e-Government failures (Aladwani, 2016) indicates how complex and global this problem can be.

This paper proposes that developing a more coordinated and engaged approach to ICT ethics should be seen as a vital part of developing ICT as a profession and that an increased sense of professional identity will foster better ethics (and vice versa). Developing the ethical dimension as part of ICT education and professional practices should contribute to increasing the status and professional identity of those who work in ICT, impacting the quality and integrity of ICT services, and reducing the risks to society of IT failures. Indeed some emerging research has indicated that a high capability of IT use can increase the ethical behaviour of companies, such as the study on the impact of effective use of IT in increased Corporate Social Responsibility in Brazilian SMEs (Malaquias, Malaquias, \& Hwang, 2016). As IT becomes more central to high level organisational strategy with the impact of digital transformation, IT professionals need to be highly capable in top leadership roles (Cano, Fernández-Sanz, \& Misra, 2013) where ethical awareness becomes more crucial.

The current lack of a coherent ethical framework for ICT is in contrast to other professions such as Medicine or Law, which have codes of ethics and possible penalties in place for noncompliance. Within the ICT field there are multiple professional bodies based on particular ICT specialities, some of which have their own codes of ethics, but there is no coordinated approach to ethics taken by the ICT industry as whole. There are also concerns about the extent to which IT education adequately prepares IT professionals for the ethical dimensions of their profession (Al-Saggaf, Burmeister, \& Schwartz, 2017) . ICT also seems to be lag behind in terms of research on its professional ethics. A recent bibliometric study (Weiss, 2017) shows that in the last 30 years, research articles on ethics in top IT or IS journals are less common than those in equivalent journals from other professions.

Additionally, there is limited data about levels of engagement and compliance with various ICT codes of ethics and there is not much known about potential international cooperation in terms of aligning them. Some work has been done within particular areas of ICT, such as how practitioners in information security view government initiatives to professionalise their work to reduce cyber threats (Reece \& Stahl, 2015). Practitioner views on ethics in ICT work contexts and the efficacy or otherwise of codes of ethics are also examined within the library and information profession (Ferguson, Thornley, \& Gibb, 2016). A study to examine the effects of stricter legal controls and penalties for unethical use of supply chain bidding IT systems in the workplace (Charki, Josserand, \& Boukef, 2017) found that effects were very mixed. In some instances, strict legal controls improved behaviour but it could also encourage efforts to find new methods of IT use to escape detection or in some cases a simple reaction of just stopping using particular IT systems.

Perhaps as a response to the challenges of actually implementing ethics in the ICT profession, there is growing interest and concern in assisting professionals in applying and incorporating ethics into their work practices and processes. Professional bodies in areas related to IT are starting to incorporate ethics into their bodies of knowledge rather than just

Thornley, C., Murnane, S., McLaughlin, S., Carcary, M., Doherty, E., and Veling, L. 2018. International Journal of Human Capital and Information Technology Professionals (IJHCITP). 2018 9(4): $56-71$. 
as 'stand-alone' codes. The Project Management Institute (PMI), for example, has included reference to taking ethics into account as part of project planning in their updated PMBOK (section 1.1.3 Code of Ethics and Professional Conduct) (P.M.I., 2017). The IEEE is currently developing a standard ("IEEE P7000 - Model Process for Addressing Ethical Concerns During System Design," 2018) to develop a process model to assist developers in addressing ethical considerations throughout the various stages of system initiation, analysis and design. These welcome recent developments will start to mitigate the relative sparseness of practical guidance but it is still the case that the bulk of work on IT or computer ethics is within the academic sphere on a conceptual or theoretical level (Floridi, 2013). In this paper we aim to reflect and engage on the actual activity and practice of developing and implementing policy initiatives to improve ethics within the context of increasing the professionalism of ICT with an international perspective.

This paper develops previous research on developing ICT as a profession through recent European Commission funded research projects (Sherry, Carcary, McLaughlin, \& O'Brien, 2013; Husing et al., 2013; McLaughlin et al., 2012; van der Linden et al., 2017) whose aim was to provide evidence informed policy guidance on developing ICT as a profession and thus ensuring agreed ethical and professional standards of practice. The initial design of the research was also presented at a conference (Thornley et al., 2016)and this paper develops that work and uses the feedback from participants to further refine its focus. The research questions examined in this paper are as follows:

RQ.1: To what extent do ethics contribute to the development of the professional identity of ICT practitioners?

RQ.2: What practices and policies can promote the development of and engagement with ICT ethics?

RQ.3: To what extent can these practices and policies be usefully coordinated internationally?

The key contribution of this paper is to provide an analysis of the challenges in developing ethics within ICT and possible policy and practice responses as identified by a range of international stakeholders, including practitioners, professional bodies, employers, and educators. It is an informative example of developing ethics within a profession and addressing the challenge of gaining engagement from practitioners on a global level.

\section{Theoretical Base}

The theoretical context in which this discussion of ICT ethics takes place is informed by work on professionalism and ethics, and the relationship between them. The original motivation of this research was to provide guidance to policy makers and practitioners involved in ICT rather than to develop a theoretical understanding per se. This research originated from a wider agenda at the EU policy level to investigate and address a practical problem concerning the fragmented and under-developed nature of the ICT profession, of which ethics is key component, and the associated difficulties relating to economic growth and the potential risk of ICT failures.

Thornley, C., Murnane, S., McLaughlin, S., Carcary, M., Doherty, E., and Veling, L. 2018. International Journal of Human Capital and Information Technology Professionals (IJHCITP). 2018 9(4): :56-71. 


\section{Ethics}

The theoretical approach to ethics taken in this study was a pragmatic consequentialist approach based on the perceived value of its positive outcomes rather than a principle/rulebased or virtue-driven approach. This was derived from the stakeholders involved for whom ICT ethics is primarily a practical problem to solve. Another factor in adopting this pragmatic approach is that the ICT profession is very diverse and operates internationally, so different cultural norms and attitudes need to be taken into account, rather than developing a rigid approach. Approaches to privacy, for example, can vary between different cultures and regions (Mijuskovic \& Ferati, 2016). Our work does not, however, reflect a simple cultural relativism. Although core ethical principles were generally agreed by all stakeholders within this research, the details of how best to implement ethics and encourage understanding and take up are likely vary, to an extent, from region to region.

Guidelines and codes of ethics exists for most ICT professional associations but implementation for practitioners can be challenging in the complexity of the workplace (Ferguson et al., 2016). In some cases, within IT, interactive codes and guidelines have been developed to make codes easier to use and apply (Campos \& Amaral, 2010). International Standards and Bodies of Knowledge can also provide some guidance but it can be challenging to identify the most relevant sections and how they apply to IT so further interpretation can be necessary. In terms of the international standard 'ISO 26000 -Social Responsibility', research has been done on highlighting to IT professionals how to identify the core subjects of ISO 26000 relevant for their organisations and thus behave in more ethical manner by taking actions towards sustainability (Zompras \& Siakas, 2015).

There are a number of specific challenges in developing ethics within the ICT profession. In the first instance, ICT is pervasive in many jobs and roles and there is no clear agreement whether ICT is distinctive and cohesive enough to be 'a profession' in the standard sense. This may mean that a standardised ethics protocol is unlikely to be workable (Weckert \& Lucas, 2013). Secondly there are also cultural and geographical differences in approaches to ICT and information management (X. Sherry, 2013)that impact on ethical issues (Kirs \& Bagchi, 2012).

Culture is also an issue on an organisational level as ICT exists in a range of organisations, including the public and private sectors, and SMEs. These can have very different value sets and cultural expectations as is discussed in recent work on the specific issues in aligning ICT ethics with public service ethics in the Canadian context (Kernaghan, 2014). In the case of public service there can also be a statutory as well as ethical imperative to, for example, provide a universal service for interacting with the state to citizens who may not have the necessary digital skills or technology. This may be in conflict with other imperatives, such as the efficient use of public funds, so there is no straightforward answer to deciding the most ethical approach to take.

Thirdly, the rapid rate of technological change in ICT means new ethical challenges tend to emerge more quickly than appropriate guidelines can be developed. Examples of such dilemmas include privacy issues arising from big data (Martin, 2015) or the tensions between efficiency and user preferences in RFID technology (Thornley, Ferguson, Weckert, \& Gibb, 2011).

Thornley, C., Murnane, S., McLaughlin, S., Carcary, M., Doherty, E., and Veling, L. 2018. International Journal of Human Capital and Information Technology Professionals (IJHCITP). 2018 9(4): :56-71. 
Finally, in most regions, women and minority groups are underrepresented in the ICT profession (Iclaves, 2013), which some participants in our research considered to be an issue of social justice that the ICT profession has an ethical imperative to address. There have been a number of international efforts to increase the number of women entering ICT courses and careers with varying degrees of impact (Miliszewska \& Moore, 2010).

\section{Professionalism}

The centrality, or otherwise, of ethics in ICT professionalism has been much discussed (Weckert \& Lucas, 2013). There is also long historical debate, or indeed controversy, as observed by (Cogan, 1955) and more recently by (Saks, 2012), about the nature of professionalism itself. This has discussed in the literature with regard to the established professions in the Victorian context (Chua \& Poullaos, 1993) and has also been highlighted as an issue with the 'newer' professions such as education (Eraut, 1994). The status of a profession has been taken to imply the ability to self-regulate on ethical matters but this is becoming less tenable as public trust in institutions and professions weakens (Eraut, 1994). Within the European Union policy arena the professionalization of IT has been a policy priority since the early 2000s with a number of projects and initiatives taken to mature IT as a profession (Sherry, Carcary, McLaughlin, \& O'Brien, 2013). Research by McLaughlin et al. (2012) developed a model of ICT professionalism within the European context, from an analysis of the literature (Agresti, 2008; Denning \& Frailey, 2011), and input from stakeholders collected through surveys and interviews. This model consists of four building blocks which are: competences; education and training; bodies of knowledge; and professional ethics.

This paper presents data on stakeholders' experiences of the professional ethics building block to inform the holistic development of all of the building blocks of the profession. Within our research, the role of ethics should be understood as part of a wider debate about what makes an effective ICT professional, which can further help ensure that ICT is used and managed in ways that benefit, rather than potentially damage, society.

\section{Methods}

\section{Research Questions}

The research questions, as detailed in the introduction, were developed through analysis of the literature and previous research on ICT professionalism, in which stakeholders had consistently identified ethics as a key component of developing ICT as a profession. This paper focuses on the input and debate around ethics though in many cases, as will be clear from some of our findings, the question of ethics needs to be closely coordinated with other professionalism issues such as education.

A qualitative research approach was adopted within this study as this is widely regarded as the most appropriate approach for studying a wide range of social dimensions, while maintaining contextual focus (Mason, 2002). Primary data were collected through a series of group and individual engagements between March 2014 and January 2017.

We first collected data from participants during a two-day international workshop on 'eSkills and ICT Professionalism', organised by the European Commission (EC) in March 2014. The workshop, similar in nature to a focus group discussion, was part of an EC funded Thornley, C., Murnane, S., McLaughlin, S., Carcary, M., Doherty, E., and Veling, L. 2018. International Journal of Human Capital and Information Technology Professionals (IJHCITP). 2018 9(4) :56-71. 
research project 'e-Skills: the international dimension and impact of globalisation' (McLaughlin et al., 2014), which was investigating the global nature of the ICT professionalism and how this should inform the initiative to mature the profession. The aim of this workshop was to collect information and viewpoints on the nature of ICT professionalism at a global level and to look at possibilities for global cooperation to increase the effectiveness of local level responses.

In preparation for the workshop all participants were asked to collate data and input from other stakeholders from their own countries on key ICT professionalism challenges and issues, and use this data to guide their workshop presentations. As such, for the purposes of this research, the members of the group were considered to represent the views of range of organisations from their country. The questions focused on the development of the four pillars of ICT professionalism already identified in previous research, i.e. ethics; competences; education and training; and bodies of knowledge.

A follow up conference call with the workshop participants and other international stakeholders was held in April 2014 and have been ongoing on an approximately quarterly basis since then. The most recent face-to-face dataset was gathered at an international conference on e-Skills held in December 2016 (van der Linden et al., 2017) during a panel discussion where experts contributed their views on progress on ICT ethics and the subsequent open discussion. We have also maintained regular contact with the workshop participants and international representatives from related organisations in the field of ICT Professionalism. This has ensured any new developments over the intervening period are fully reflected in the findings presented in this paper.

\section{Data sources}

The primary data analysed in this research came from a number of key sources:

\section{International workshop}

- Content of each e-skills stakeholder presentation on e-skills in their specific locale

- Qualitative data captured from discussion amongst key stakeholders throughout the course of the 2-day workshop

- Qualitative data captured from discussion amongst key stakeholders during follow up conference calls

Conference calls and one to one calls

- Updates provided by stakeholders regarding new developments in ICT professionalism in their regions

\section{Ethics panel discussion}

- Preparatory notes from participants

- Qualitative data captured from discussion amongst key stakeholders at ethics panel discussion at e-skills conference

\section{Research participants}

Although it is not possible to avoid bias completely in participant selection, strenuous efforts were made to ensure that only expert contributors to the ICT professional domain were invited. Participants were also from ICT professional or government organisations and, as

Thornley, C., Murnane, S., McLaughlin, S., Carcary, M., Doherty, E., and Veling, L. 2018. International Journal of Human Capital and Information Technology Professionals (IJHCITP). 2018 9(4): :56-71. 
such, represented a diverse range of members and stakeholders rather than the interests of particular companies or institutions. They were also asked to bring data and viewpoints from other stakeholders in their respective regions to provide as thorough a representation as possible.

\section{International workshop and follow on calls}

The participants of the international workshop were key international stakeholders from professional associations, industry bodies and government institutions selected through purposeful sampling. They were selected through an examination of key contributors in the ICT professionalism debate internationally and to ensure the widest geographical spread possible. In advance of final decisions being made on participants, all potential participants were engaged in a conference call to ensure the appropriate level of potential input and that the correct personnel from the organisation had been selected. Finally, the participants had to be approved by the European Commission.

In total there were 17 participants: the geographical distribution and the nature of their respective organisations are detailed in Table 1. While efforts were made to include the most international representation possible, it is acknowledged that more developed countries are represented than developing countries. All expenses were reimbursed for participants but it is accepted that other barriers do exist to a fuller global participation and this is an acknowledged weakness of our data. One possible explanation came from the South African participants who noted that in Africa, for example, many other developmental and ethical issues were more of a priority than those of ICT professionalism.

\begin{tabular}{|c|c|}
\hline Country & Participant Organisation \\
\hline European Perspective & $\begin{array}{l}\text { - European Commission } \\
\text { - Innovation Value Institute (IVI) } \\
\text { - Empirica Research Ltd } \\
\text { - Council of European Professional Informatics Societies } \\
\text { (CEPIS) }\end{array}$ \\
\hline Australia & - Australian Computer Society \\
\hline Brazil & $\begin{array}{l}\text { - Brazilian Association of Information Technology and } \\
\text { Communication Companies (BRASCOMM) }\end{array}$ \\
\hline Canada & - Information and Communications Technology Council \\
\hline Chile & $\begin{array}{l}\text { - Asociacion Chilena de Empresas de Tecnologia de } \\
\text { Informacion A.G (ACTI) [The Chilean Association for IT } \\
\text { Companies] }\end{array}$ \\
\hline Japan & - Information-Technology Promotion Agency (IPA) \\
\hline Malaysia & - Malaysia Knowledge Workers Development Centre (MSC) \\
\hline Russia & $\begin{array}{l}\text { - Lomonosov Moscow State University, Faculty of } \\
\text { Computational Mathematics and Cybernetics (CMC MSU) }\end{array}$ \\
\hline
\end{tabular}

Thornley, C., Murnane, S., McLaughlin, S., Carcary, M., Doherty, E., and Veling, L. 2018. International Journal of Human Capital and Information Technology Professionals (IJHCITP). 2018 9(4): :56-71. 


\begin{tabular}{|l|l|}
\hline & $\begin{array}{l}\text { ICT Skills Workshop Chair (204), Russian National Body of } \\
\text { Standardization Technical Committees «Information } \\
\text { Technology» (TC-ITC-22) }\end{array}$ \\
\hline South Africa & $\begin{array}{l}\text { Ikamva National eSkills } \\
\text { [not present at the e-skills workshop but attended follow- } \\
\text { up conference call] }\end{array}$ \\
\hline $\begin{array}{l}\text { International } \\
\text { perspective, inc. USA }\end{array}$ & $\begin{array}{l}\text { Institute of Electrical and Electronics Engineers Computer } \\
\text { Society (IEEE CS) } \\
\text { Association for Computing Machinery (ACM) }\end{array}$ \\
\hline
\end{tabular}

Table 1: Participation in Workshop and Calls by country/region

\section{Ethics Panel Discussion}

The Ethics panel discussion was a panel session during an international conference on eSkills, held in Brussels in December 2016 (van der Linden et al., 2017). Four invited experts, as detailed in Table 2, presented different aspects and perspectives on ethical issues in relation to the development of an ICT Profession, before answering questions from the floor. In a similar way to the international workshop participants these were acknowledged leaders in the ICT Professionalism field. All participants to the conference were also on an invitation only basis to ensure that only knowledgeable experts from a representative range of organisations attended.

\begin{tabular}{|l|l|}
\hline Country & Participant Organisation \\
\hline Europe & Council of European Professional Informatics Societies (CEPIS) \\
\hline UK & University of Greenwich \\
\hline Spain & Mind Your Privacy group \\
\hline The Netherlands & CIO Platform Nederland \\
\hline
\end{tabular}

Table 2: Participation in Ethics Panel by country/region

\section{Methods of analysis.}

The qualitative data from workshops, calls and the conference was captured by two researchers who compared and validated their data to ensure completeness and accuracy. After all interactions, all participants were also contacted to update any policy initiatives they had discussed at the event and to validate the transcription/interpretation. Using the respondent validation technique (Bryman \& Bell, 2015) specific research findings were returned to relevant participants for their comments and to ensure clarity. This data was then analysed using qualitative coding techniques (Mostyn, 1985), which resulted in the identification of key concepts/themes. Comparative analysis and iterative reflection on the emerging codes/themes (Alvesson \& Sköldberg, 2010) supported development of insights in relation to the key findings. In terms of representing the proportional range of the views of the various participant a numerical percentage approach was not taken as a wide range of Thornley, C., Murnane, S., McLaughlin, S., Carcary, M., Doherty, E., and Veling, L. 2018. International Journal of Human Capital and Information Technology Professionals (IJHCITP). 2018 9(4) :56-71. 
views were discussed and levels of agreement does not necessarily indicate importance, particularly given the relatively small number of participants. This is in line with qualitative method guidance on similar studies (Walsham, 1993). We have, however, highlighted when there was almost complete agreement or considerable disagreement as this does provide some broad indication of the current state of the debate.

\section{Findings}

In this section the findings relating to each key research question are reviewed based on the full range of data sources.

\section{RQ.1 To what extent do ethics contribute to the development of the professional identity of ICT practitioners?}

A clear majority of participants at the workshop agreed that ethics was a very important issue for the ICT profession but also a difficult one to address. Despite the initial pragmatic framing of the research, many participants evoked a principled stance based on duties and their own professional identity when questioned on ethics in ICT. A key difficulty, however, is that different countries, and indeed sectors, have different definitions or views on what constitutes an ICT professional. So, in terms of analysing the role that ethics contribute to the professional identity of ICT professionals, there is a challenge in that there is no universally accepted, clear, and formalised view on what an ICT professional actually is. Indeed, there is no universal consensus that it should be seen as a profession. As was observed at the panel discussion, ICT ethics cannot be totally tied to a universal concept of professionalism, as we cannot assume all countries see ICT as a profession and we need to remember that "some do not!".

Related to this challenge, there are very few barriers to entry to the ICT profession, with many people working in the field being self-taught or without formal qualification. In general, employers look for someone who has experience and are less concerned about qualifications and certification; but this can have implications if people are writing code for safety critical applications. Disagreement about how to address this without being overly restrictive can be make it very challenging to get agreement within the ICT Profession about how ethics can or should be included in the concept of an ICT Professional because the concept itself is uncertain.

This does remain an ongoing challenge for ICT and as one participant at the ethics panel noted, some ICT professionals may see ethics either "as a pillar of their profession" or as "more of a pillory which cannot be taken seriously".

There were also differing views as to whether the standard view of a profession, as for example in Medicine or Law, could really be usefully applied to ICT. As discussed, however, it was felt strongly that most practitioners working in ICT did have a sense of professionalism as regards their particular role but did not perhaps feel part of wider professional circle. A strong sentiment from all the participants from whom we gathered data was that ICT is so pervasive that it was very challenging to develop usable universal ethical guidelines.

All workshop participants, for example, agreed that ICT professionals may well have played a contributory role in the banking crisis in 2008 , but their responsibility vis à vis those working

Thornley, C., Murnane, S., McLaughlin, S., Carcary, M., Doherty, E., and Veling, L. 2018. International Journal of Human Capital and Information Technology Professionals (IJHCITP). 2018 9(4) :56-71. 
in the business functions was difficult to establish. In many cases ICT professionals are outside the 'circle of power' in organisations, partly as a result of the lack of professional status, and do not have the authority to call a halt to unethical practices that rely on ICT. Does responsibility just end with the requirement to ensure that the IT system is secure and effective? Or does an ICT professional also have some responsibility for the potential uses ethical and unethical - to which even a sound system may be put?

Within what can be termed the ICT profession there are many different areas of work including creating systems and products as well as implementing and guiding their use in organisations. The perspective of the systems developer was highlighted at the ethics panel in terms of the pressure to get new products to market first, which was often stronger than the desire to make the product correct or secure. The relationship between the developer or vendor of an ICT product and the user was seen as complex in terms of ethical responsibility. There is not only the question of ethics in system design, but also a separate, albeit related, question of ethical use of the system. Within the Netherlands the professional ICT association, CIO Platform Nederlands, had developed a code of conduct to help clarify the relationship between vendors and those that buy the products to increase transparency but it was felt this could certainly not be imposed on vendors. Their conclusion was that "both sides of the market will need to step up and ethics will be a large part in that. We need a new set of ethics to guide us in this relationship".

The growth in contract based work and increased job insecurity was seen to make this more of a problem in terms of silencing whistle blowers. This shows that the ethical behaviour of any profession or role cannot be understood in isolation from what could be argued as the ethical context of their employment situation. The growth of data science is an issue which has gained prominence since our initial data collection in 2014. During the 2016 ethics panel discussion, one participant raised the problem that requests for use of data could be compliant but still "borderline when it comes to data ethical issues". Suggestions to address this included clear escalation mechanisms when employees felt uncomfortable and perhaps an external body such as an ethics board who could consider these cases.

The question of what counts as an ethical issue for ICT was also raised, though there were different views on this at the workshop, and no final consensus from participants. Currently, for example, women and minority groups are underrepresented in ICT roles but is this a pragmatic employment market issue or a wider one of inclusion and balance in terms of equitable access to well-paid and stimulating careers? Does the ICT profession have a role to play in terms of integrating people into employment and wider society through working in ICT? ICT's potential to overcome barriers to employment in terms of, for example, disability and distance, could certainly contribute to creating a fairer, more accessible employment market, and it perhaps has a clearer potential role to play in this area than some more established professions.

It was agreed by all countries represented at the workshop that some kind of internationally agreed definition of an ICT professional, which also clearly explained the different types of roles it involved, would be very useful. This would enable more effective comparison internationally and enable initiatives on ethics to have clear target audience. It would also

Thornley, C., Murnane, S., McLaughlin, S., Carcary, M., Doherty, E., and Veling, L. 2018. International Journal of Human Capital and Information Technology Professionals (IJHCITP). 2018 9(4) :56-71. 
enable more accurate tracking of the gender, age, and demographic profile of ICT workers, to identify which groups are currently underrepresented.

\section{RQ.2 What practices and policies can promote the development of and engagement with ICT ethics?}

The difficulties associated with defining and delineating ethical responsibility in the integrated and diffuse roles of ICT, which often supports rather than leads organisational activities, is particularly challenging. Participants' experiences at the workshop of addressing such issues varied considerably. There were, however, a number of interesting examples of successful practices and policies, detailed in this section, some of which begin to show progress in integrating ethics as an essential part of other pillars of ICT professionalism, i.e. education and training; bodies of knowledge; and competences. A key insight that came from a participant at the international workshop was that for progress in ICT professionalism to happen we needed to see these as "not pillars but bodily organs that need to work together".

Education and continuing professional development (CPD) were seen by all workshop participants as a potentially crucial mechanism for strengthening practitioners' engagement with ethics from the outset, although some countries are far more developed in this area than others. In Canada, for example, ethics are integrated into the ICT curriculum. In Malaysia an assessment tool had been developed known as 'i-Citizen' that evaluates ICT ethics awareness and is being rolled out through the education system including at primary level.

There were interesting dilemmas raised in one follow on conference call relating to "what not to teach" in terms of ethics. For example, on an information security module it was felt important to teach enough to allow students to prevent malicious cyber security attacks but there was an obligation not to inadvertently teach them how to mount such an attack. This was felt to be a complex area with difficult boundaries and, unlike in a workplace, where employees can be vetted and trust developed over years, university students were normally admitted to a course simply on their academic results.

Related to integrating ethics into education is the question of integrating ethics into ICT Bodies of Knowledge (BoK). The Institute of Electrical and Electronics Engineers (IEEE), for example, is planning to include a chapter on ethics in the revised Enterprise ICT BoK ("EITBOK," 2018)which will be based on the IEEE code of ethics and other reference material. The future plan is to then map curricula to this revised BoK so that ethics will also become integrated into education. This point was further expanded at the ethics panel discussion as a way to avoid the tendency for ethics to be seen as a purely restrictive rather than enabling activity. As it was put by one participant at the panel "IT professionals are often accused of being the people that put NO in technology". It was proposed that the use of ethics frameworks can provide a shared understanding and basis for discussion around ethics, which can be especially important in such a globalised profession. The aim would be for questions such as 'what are the unforeseen implications?' or 'should we do this?' to have a reference guide to inform debate.

Thornley, C., Murnane, S., McLaughlin, S., Carcary, M., Doherty, E., and Veling, L. 2018. International Journal of Human Capital and Information Technology Professionals (IJHCITP). 2018 9(4) :56-71. 
The IEEE is also starting to develop a new set of standards, whose proposed scope is to establish a process model by which engineers and technologists can address ethical considerations throughout the various stages of system initiation, analysis, and design. The expected Process Requirements include: The Management and Engineering View of New IT Product Development; Computer Ethics and IT System Design; Value-Sensitive Design; and Stakeholder Involvement in Ethical IT System Design. These initiatives involving education and bodies of knowledge are examples of how ethics are being explicitly integrated into the other pillars of ICT professionalism. Integration and mapping of ICT bodies of knowledge, occupational profiles and competence frameworks (Fernández-Sanz, Gómez-Pérez, \& Castillo-Martínez, 2017) has recently been further developed which has the potential to further assist efforts to integrate ethics. A current project (van der Linden, 2017) also focuses on integrating organisational frameworks with skills frameworks with further potential for 'mainstreaming' ethics.

Professional associations are also doing some interesting work in making ethical guidelines more adaptable and easy to use by professionals. Within the EU, the Council of European Professional Informatics Societies (CEPIS), for example, has done some work using stories and other tools to facilitate discussion and development of ethical understanding ("CEPIS Ethics," 2017). CEPIS has also just established a Special Interest Network on Professional Ethics, with a focus on the practical supports that are needed by professionals and professional bodies. The Spanish ICT professional body the Spanish Informatics Engineering Council has made significant progress in developing an accepted code of ethics in collaborative fashion with members using a questionnaire to gather information on member priorities. The details of this were discussed in follow up calls and it was explained that they had delayed work on this initiative until a more agreed European wide approach in the form of the CEPIS guidelines was in place to inform their plans. A key aim for their work on ethics is to unify the current diverse regional codes and the codes for different sections of the ICT profession, e.g. forensics, software development. This demonstrates the value that is seen in a coordinated and planned approach to developing ethics within the ICT profession.

Similarly, the Australian Computer Society (ACS) has developed extensive ethics case studies to show the relevance of ethics in various ICT professional contexts ("ACS Code of Professional Conduct Case Studies," 2014) and earlier versions of these have been favourably reviewed and deemed relevant for related professions (Ferguson, Salmond, AlSaggaf, Bowern, \& Weckert, 2005). The ACS's own evaluation of these case studies have shown increased interest and involvement in ethical issues within the profession and positive feedback was given on this work by the Australian representative at the workshop.

The issue of penalties for non-compliance or restrictions to practice were felt by most workshop participants to be appropriate in certain safety critical or sensitive areas such as healthcare or aerospace as the implications of failure can potentially be catastrophic - often literally a matter of life or death. A 'licence to practice' is used in many professions as a safeguard that only professionals who have studied, been certified, and adhere to certain professional and ethical standards are allowed to practice. This was also mentioned in the panel discussion, outlining the current situation of a voluntary sign up to a code of ethics when (and if) ICT professionals join their relevant professional association but this is typically about $5-10 \%$ of ICT professionals in most countries. It was felt by one expert from the panel Thornley, C., Murnane, S., McLaughlin, S., Carcary, M., Doherty, E., and Veling, L. 2018. International Journal of Human Capital and Information Technology Professionals (IJHCITP). 2018 9(4): :56-71. 
that "the voluntary sign-up, which brings with it an ethical code of conduct, is not actually really delivering for us".

A participant from the floor during the panel discussion, however, outlined an initiative in the Netherlands where the Dutch Computer Society had started an initiative to let ICT professionals take an 'ICT vow' on ethics and a recent targeting of a large hacking conference had resulted in many young people taking this vow. This led to a discussion about the relative role and importance of the organisation and the individual in ethics. It was felt that this did have to be top down in terms of a clear message of 'this is how we do things in our organisation' but that also an individual personal commitment was important and that oaths and vows could play a role here in reminding and reinforcing the importance of ethical behaviour. There was some agreement between participants that this could be encouraged and that organisations could advertise the fact that their staff had taken such an oath and that this may influence people choosing their business. Indeed, there was a strong belief that consumer demand for more ethical transparency in organisations would signal the value of ethical practices to organisations, who would in turn encourage and promote these ethical practices, thereby driving quicker behavioural change.

Throughout all the interactions with participants in the different engagements a strong message emerged that the varied nature of ICT makes implementing and enforcing a certification or 'licence to practice' highly problematic. In fact, most participants reported that there had been strong resistance to any proposals for licencing of the ICT profession in their country. In Malaysia, for example, an initiative to develop a Board of Computing Professionals Malaysia was originally planned to be developed through a formal Act of Parliament. Following consultation with the various stakeholders, however, it was decided to go down the route of an Association which is recognised by the Government instead of an Act of Parliament. The formal legal recognition of professional licensing was seen as unworkable by the ICT profession itself.

This view was echoed in the ethics panel where one participant said that "enforced licencing would only make the problems of ICT recruitment even more serious and be unworkable" because of pressure due to the shortage of skills in the industry and effort involved in licensing. It was also acknowledged that there was a lack of robust research to support the view that licensed or certified ICT professionals actually did perform better than those that were not. In the discussion it was also argued that being a licensed professional did provide confidence in a person's competence, commitment to the profession, CPD and ethics. As an ICT profession we do need to ask ourselves how much longer society will tolerate big ICT project failures resulting from (for example) poorly written or incompatible code. This was summarised neatly by one panel expert: "we have a duty of care to the public".

\section{RQ.3 To what extent can these practices and policies be usefully coordinated internationally?}

Ethics was agreed to be a very important issue by all participants we engaged with, however, an agreed international code of ethics was not seen as a realistic option at this stage. CEPIS, the European body for ICT professionals, had recently published guidelines on developing codes of ethics, which are discussed in a recent European Commission report (van der Linden et al., 2017). These guidelines addressed what should be included in a code of ethics

Thornley, C., Murnane, S., McLaughlin, S., Carcary, M., Doherty, E., and Veling, L. 2018. International Journal of Human Capital and Information Technology Professionals (IJHCITP). 2018 9(4) :56-71. 
and why, however, this was to encourage broad consistency across Europe rather than to prescribe a universal code.

Different countries and professional associations have their own codes and it was also agreed by all that in some particularly sensitive contexts, e.g. ICT in health, ethics should be more strictly regulated. Ethics is a challenging area for ICT and, at present, there would appear to be no clear consensus on the best way forward. There are also important differences about who should take responsibility for ethics. In Japan, for example, a 'code of ethics' is typically developed by companies independently and signed off by their employees. This takes place within the Japanese tradition of career long service to one employer. In such in Europe, the USA and Australia, however, codes of ethics are more likely to originate from nationally coordinated professional bodies.

One suggestion that came out the Ethics Advisory Group of the European Data Protection Supervisor Ethics Advisory Board, as highlighted by one of the panellists, was to learn from other labelling and certification initiatives, such as food traceability. European coordination in terms of labelling traceable software could be one way ahead. It was felt that any initiative of this sort would at least require European coordination to be workable.

Another important difference was the level of development of the different countries. From the perspective of participants from South Africa the ICT professionalism debate needed to be seen as part of the wider developmental context. Africa also faces a range of different social issues which pose additional challenges and are perhaps higher up the ethical agenda than discussing ICT professional ethics. When tackling the challenge on a global basis, it should be remembered that the fundamental problem of providing primary and secondary education for all the children in the world has not been solved. Political instability can also slow down progress and this had happened with work on a shared competency framework in Africa. Similarly, the enormous political transitions that have occurred over the last 25 years in Eastern Europe and the former Soviet Union are also still having effects on the nature of ICT professionalism in those countries.

Whether the under representation of women and minorities was counted as a priority issue within the developing ICT profession also varied. The position of women in society, cultural expectations, and employment structures provided for mothers who wish to continue working in ICT was one factor. In the former Eastern bloc countries, women were generally equally represented in the ICT profession and there was little understanding from these regions as to how this could not be the case for the rest of the world.

The research shows that stakeholders see some policy responses as being necessarily global, whilst some are perhaps better tackled on a national level. Even at a national level, some countries, for example the USA and Australia, have challenges in implementing a unified ICT professionalism policy due to the localised nature of some service provision such as education. Table 3, summarises the relevant policy responses.

\begin{tabular}{|l|l|l|}
\hline Challenge & Response & Location \\
\hline
\end{tabular}

Thornley, C., Murnane, S., McLaughlin, S., Carcary, M., Doherty, E., and Veling, L. 2018. International Journal of Human Capital and Information Technology Professionals (IJHCITP). 2018 9(4): :56-71. 


\begin{tabular}{|l|l|l|}
\hline \multirow{2}{*}{$\begin{array}{l}\text { Low take up and use } \\
\text { of ethical guidelines }\end{array}$} & $\begin{array}{l}\text { Creating tools to facilitate learning and show } \\
\text { relevance }\end{array}$ & EU \& Australia \\
\cline { 2 - 3 } & Integrating ethics into ICT education & Canada \\
\cline { 2 - 3 } & $\begin{array}{l}\text { Teaching ICT ethics prior to third level } \\
\text { education }\end{array}$ & Malaysia \\
\cline { 2 - 3 } & $\begin{array}{l}\text { Integrating ethics into Bodies of Knowledge } \\
\text { and competence/skills frameworks }\end{array}$ & $\begin{array}{l}\text { USA, possibly EU } \\
\text { with e-CF and } \\
\text { SFIA updates }\end{array}$ \\
\hline
\end{tabular}

Table 3: National response to implementing ethical guidelines

This can make changes difficult to implement quickly, which is a particular problem in such a fast moving field as ICT. There is a tension between developing a rapid policy response based on international level expertise whilst also maintaining relevance and acceptance at a more local level. As part of the international project conference calls, one participant from South Africa argued that "coordinated strategies are necessary rather than disjointed interventions that go nowhere".

\section{Implications and Discussion}

This study provides some insights into the complexity of ethics within the ICT profession but its implications are much wider. ICT is now so pervasive that the distinctions - and indeed, the overlaps - between ICT ethics and, for example, medical or business ethics are likely to become more blurred. Information, often in a specialised expert form, is an essential component of what a profession is, and increasingly this information will be manipulated and used by complex and ubiquitous ICT systems. Thus, it is essential for all professions that there is a clear understanding of the ethical dimensions of ICT.

It also shows that developing ethics in the abstract may be relatively straightforward; for example, many professional ICT bodies already have codes of ethics. Ensuring full engagement from practitioners, combined with the empowerment to act on such codes, however, was not seen as straightforward by participants. This viewpoint has been well documented in previous research (Healy \& Iles, 2002). The tension and the relationship between compliance and ethics that was raised during this work has also been discussed in previous work (Ferguson et al., 2016) on the viewpoints of practitioners in terms of professional ethics. Our findings on the potentially unforeseen and negative effects of stricter regulation, for example in terms of the certification of ICT professionals, reflects similar findings to work on the mixed effects of increased penalties for unethical ICT use (Charki et al., 2017).

Finally, no efforts to improve ethics in the workplace can now ignore the global context, but this study of ICT ethics demonstrates that this global view also presents new challenges of coordination and possible cultural conflict. In terms of effective policy response, our findings reflect other work on the need for reliable data and the complexities involved (Merkofer \& Murphy, 2009), as well as the need to take on board cultural differences (X. Sherry, 2013). Thornley, C., Murnane, S., McLaughlin, S., Carcary, M., Doherty, E., and Veling, L. 2018. International Journal of Human Capital and Information Technology Professionals (IJHCITP). 2018 9(4) :56-71. 
The differences between countries and areas in terms of levels of development, language, and political contexts do matter, both in the global sense and within Europe. In terms of global development, for some regions other issues apart from ICT professionalism will currently take priority, as some more basic infrastructural issues need to be solved first. Despite these differences, there is strong desire both to learn about effective practices from other countries, and to cooperate on initiatives that require a global response. It was agreed by all participants that addressing the challenges around ICT professionalism is a social and economic imperative, which will enable the positive effects of technology to be realised for international benefit.

Ethics does seem to be central to the concept of being an ICT professional for many people working in ICT, though there is no unified view on what this means exactly, as the concept of ICT professionalism itself appears to be a somewhat imprecise concept. This finding reflects an ongoing topic of debate in IT or computer ethics on which there is still no clear agreement (Weckert \& Lucas, 2013). An important contribution of this research is showing how the lack of a definition as to what counts as an 'ICT professional' is a serious inhibitor in both collecting accurate data and allowing valid international comparisons to be made.

Participants felt that this also extended to the real practical difficulties of defining ICT roles when ICT is increasingly ubiquitous through different organisational functions and sectors. This also reflects the problem of effectively incorporating ICT ethics into professions or sectors that already have clear ethical guidelines (Kernaghan, 2014). There remains an acknowledged tension between overly defining roles to provide clarity whilst still maintaining the flexibility and complex skill set needed for most ICT careers.

In some cases, initiatives to attract women and girls, for example, had focused on the broad reach of ICT careers to include health and creative industries, etc. Overly rigid definitions of ICT professionalism could therefore hinder these efforts. This is reflected in concerns about being overly prescriptive about ethics and thereby creating unusably rigid guidelines. These concerns regarding the tensions within professionalism and ethics are also reflected in the literature (Brady, 2009; Weckert \& Lucas, 2013). Acknowledging and successfully managing these tensions will be central to developing useful and workable ethical guidelines for ICT professionalism.

\section{Conclusions}

The pertinent actions to be taken, or relevant conclusions to be drawn, from this research will vary between different stakeholders. In terms of what it means for people working within ICT who are concerned about ICT ethics and ICT professionalism in general, it suggests that active engagement with the relevant ICT professional bodies at a national (and possibly international) level is a useful course of action. These complex issues can only be successfully worked upon at a policy level if as many different views and perspectives from the ICT profession are taken on board, both to more accurately formulate the problem and to develop workable solutions. Cooperation with those supporting ICT professionals such as HR professionals and education professionals will also be important to improve outcomes.

Thornley, C., Murnane, S., McLaughlin, S., Carcary, M., Doherty, E., and Veling, L. 2018. International Journal of Human Capital and Information Technology Professionals (IJHCITP). 2018 9(4): :56-71. 
In terms of global and national policy makers coordinating policies, in consultation with the relevant professional bodies, would appear to be key whilst acknowledging that important cultural differences do exist. Even though each of the represented economic regions identified with the same core issues, the respective journeys they had embarked upon were different in terms of their starting point, focus, and how far they've progressed. Although the core issues are well understood at a global level, the required solutions need to consider local, cultural, economic, educational, and legislative issues.

The need for closer collaboration between the economic regions was identified, so as to ensure best and appropriate practices are identified and shared effectively. Contrarily, to ensure these solutions are effectively implemented, a 'bottom-up' approach looks likely to them to be the most effective. This will necessitate the support and inclusion of all triple helix stakeholders (academia, government, and industry) in identifying how best to engage and work together. A key challenge is in identifying representative bodies for both industry and academia who have the authority and resolve to develop working solutions to the ethical challenges surrounding the ICT profession.

Our research provides some new insights into how some key stakeholders perceive the nature of this challenge and their views on useful policy responses at both a national and international level. Developing effective and meaningful ethical guidelines and practices for those working in ICT is a global problem which is currently being worked on by many committed stakeholders but progress will require long term persistence and wider engagement.

\section{Funding}

The ICT Professionalism policy projects on which this research is based were made possible by funding from the European Commission.

The international workshop was funded as part of the 'e-Skills: the international dimension and the impact of globalisation' project funded by the European Commission, reference 198/PP/ENT/CIP/12/C/N01CO23

The panel discussion at the conference was part of 'The Development and Implementation of a European Framework for IT Professionalism' project funded by the European Commission, reference, EASME/COSME/2014/012

\section{References}

Thornley, C., Murnane, S., McLaughlin, S., Carcary, M., Doherty, E., and Veling, L. 2018. International Journal of Human Capital and Information Technology Professionals (IJHCITP). 2018 9(4) :56-71. 
ACS Code of Professional Conduct Case Studies. (2014). Retrieved August 18, 2017, from https://more.acs.org.au/_data/assets/pdf_file/0004/30964/ACS_Ethics_Case_Studi es_v2.1.pdf

Agresti, W. W. (2008). An IT Body of Knowledge: The Key to an Emerging Profession. IT Professional, 10(6), 18-22. https://doi.org/10.1109/MITP.2008.115

Aladwani, A. M. (2016). Corruption as a source of e-Government projects failure in developing countries: A theoretical exposition. International Journal of Information Management, 36(1), 105-112. https://doi.org/10.1016/j.ijinfomgt.2015.10.005

Al-Saggaf, Y., Burmeister, O. K., \& Schwartz, M. (2017). Qualifications and ethics education: the views of ICT professionals. Australasian Journal of Information Systems, 21. https://doi.org/10.3127/ajis.v21i0.1365

Alvesson, M., \& Sköldberg, K. (2010). Reflexive Methodology New Vistas for Qualitative Research/. London: SAGE. Retrieved from https://us.sagepub.com/enus/nam/reflexive-methodology/book233406

Brady, D. (2009). A Profession for IT? CEPIS UPGRADE The European Journal for the Informatics Professional, $X(4)$.

Bryman, A., \& Bell, E. (2015). Business Research Methods. Oxford University Press.

Campos, H., \& Amaral, L. (2010). GOTOPS: Code of Technoethics Governance. International Journal of Human Capital and Information Technology Professionals (IJHCITP), 1(3), 54-68. https://doi.org/10.4018/jhcitp.2010070104

Cano, C., Fernández-Sanz, L., \& Misra, S. (2013). Featuring CIO: Roles, Skills and Soft Skills. International Journal of Human Capital and Information Technology Professionals (IJHCITP), 4(1), 22-33. https://doi.org/10.4018/jhcitp.2013010103

Thornley, C., Murnane, S., McLaughlin, S., Carcary, M., Doherty, E., and Veling, L. 2018. International Journal of Human Capital and Information Technology Professionals (IJHCITP). 2018 9(4) :56-71. 
CEPIS Ethics. (2017). Retrieved from https://www.cepis.org/index.jsp?p=940\&n=2849

Charki, M. H., Josserand, E., \& Boukef, N. (2017). The paradoxical effects of legal intervention over unethical information technology use: A rational choice theory perspective. The Journal of Strategic Information Systems, 26(1), 58-76. https://doi.org/10.1016/j.jsis.2016.07.001

Chua, W. F., \& Poullaos, C. (1993). Rethinking the profession-state dynamic: The case of the Victorian charter attempt, 1885-1906. Accounting, Organizations and Society, 18(78), 691-728. https://doi.org/10.1016/0361-3682(93)90049-C

Cogan, M. L. (1955). The Problem of Defining a Profession. The ANNALS of the American Academy of Political and Social Science, 297(1), 105-111. https://doi.org/10.1177/000271625529700114

Denning, P. J., \& Frailey, D. J. (2011). Who are we---now? Communications of the ACM, 54(6), 25. https://doi.org/10.1145/1953122.1953133

EITBOK. (2018). Retrieved June 16, 2017, from http://eitbokwiki.org/Main_Page

Eraut, M. (1994). Developing Professional Knowledge and Competence. London: Falmer Press.

Ferguson, S., Salmond, R., Al-Saggaf, Y., Bowern, M., \& Weckert, J. (2005). Case studies and codes of ethics: the relevance of the ACS experience to ALIA. The Australian Library Journal, 54(3), 299-308. https://doi.org/10.1080/00049670.2005.10721766

Ferguson, S., Thornley, C., \& Gibb, F. (2016). Beyond codes of ethics: how library and information professionals navigate ethical dilemmas in a complex and dynamic information environment. International Journal of Information Management, 36(4), 543-556. https://doi.org/10.1016/j.ijinfomgt.2016.02.012

Thornley, C., Murnane, S., McLaughlin, S., Carcary, M., Doherty, E., and Veling, L. 2018. International Journal of Human Capital and Information Technology Professionals (IJHCITP). 2018 9(4) :56-71. 
Fernández-Sanz, L., Gómez-Pérez, J., \& Castillo-Martínez, A. (2017). e-Skills Match: A framework for mapping and integrating the main skills, knowledge and competence standards and models for ICT occupations. Computer Standards \& Interfaces, 51, 3042. https://doi.org/10.1016/j.csi.2016.11.004

Floridi, L. (2013). The Ethics of Information. Oxford, New York: Oxford University Press.

Healy, M., \& Iles, J. (2002). The Establishment and Enforcement of Codes. Journal of Business Ethics, 39(1-2), 117-124. https://doi.org/10.1023/A:1016392203507

Husing, T., Korte, W., Fonstad, N., Lanwin, B., Catteneo, G., Kolding, M., ... van Welsum, D. (2013). e-Leadership: e-Skills for Competitiveness and Innovation Vision, Roadmap and Foresight Scenarios. European Commission.

Iclaves, S. (2013). Women active in the ICT sector. European Commission. Retrieved from https://publications.europa.eu/en/publication-detail/-/publication/9153e169-bd6e4cf4-8638-79e2e982b0a3

IEEE P7000 - Model Process for Addressing Ethical Concerns During System Design. (2018). Retrieved February 5, 2018, from http://sites.ieee.org/sagroups-7000/

Kernaghan, K. (2014). Digital dilemmas: Values, ethics and information technology: Values, Ethics and Information Technology. Canadian Public Administration, 57(2), 295-317. https://doi.org/10.1111/capa.12069

Kirs, P., \& Bagchi, K. (2012). The impact of trust and changes in trust: A national comparison of individual adoptions of information and communication technologies and related phenomenon. International Journal of Information Management, 32(5), 431-441. https://doi.org/10.1016/j.ijinfomgt.2012.02.003

Thornley, C., Murnane, S., McLaughlin, S., Carcary, M., Doherty, E., and Veling, L. 2018. International Journal of Human Capital and Information Technology Professionals (IJHCITP). 2018 9(4) :56-71. 
Malaquias, R. F., Malaquias, F. F. O., \& Hwang, Y. (2016). Effects of information technology on corporate social responsibility: Empirical evidence from an emerging economy. Computers in Human Behavior, 59, 195-201. https://doi.org/10.1016/j.chb.2016.02.009

Martin, K. E. (2015). Ethical Issues in the Big Data Industry. MIS Quarterly Executive, 14(2), 6785.

Mason, J. (2002). Qualitative researching. London: Sage.

McLaughlin, S., Sherry, M., Carcary, M., O’Brien, C., Fanning, F., Theodorakis, D., ... Farren, N. (2012). e-Skills and ICT Professionalism Fostering the ICT Profession in Europe. The European Commission.

McLaughlin, S., Sherry, M., Doherty, E., Carcary, M., Thornley, C., Kolding, M., ... Kmek, M. (2014). e-Skills: The International Dimension and the impact of Globalisation. European Commission.

Merkofer, P., \& Murphy, A. (2009). The e-skills landscape in South Africa: The issues of demand and supply and the use of international benchmarks to inform the South African e-skills development context. Zeitschrift Für Politikberatung, 2(4), 685-695. https://doi.org/10.1007/s12392-010-0219-y

Mijuskovic, A., \& Ferati, M. (2016). Cloud Storage Privacy and Security User Awareness: A Comparative Analysis between Dutch and Macedonian Users. International Journal of Human Capital and Information Technology Professionals (IJHCITP), 7(3), 1-18. https://doi.org/10.4018/IJHCITP.2016070101

Miliszewska, I., \& Moore, A. (2010). Encouraging Girls to Consider a Career in ICT: A Review of Strategies. Journal of Information Technology Education, 9, 143-166.

Thornley, C., Murnane, S., McLaughlin, S., Carcary, M., Doherty, E., and Veling, L. 2018. International Journal of Human Capital and Information Technology Professionals (IJHCITP). 2018 9(4) :56-71. 
P.M.I. (2017). PMBOK Guide - Sixth Edition + Agile Practice Guide (6th ed.). Project Management Institute, Inc., 14 Campus boulevard, Newtown Square, Pennsylvania 19073-3299 U.S.A.: Project Management Institute, Inc. Retrieved from https://drm.pmi.org/Default.aspx?doc=PMBOKGuideAgilePG.pdf\&r=https\%3a\%2f\%2f www.pmi.org\%2fpmbok-guide-standards\%2ffoundational\%2fpmbok\%2fsixth-edition

Reece, R. P., \& Stahl, B. C. (2015). The professionalisation of information security: Perspectives of UK practitioners. Computers \& Security, 48, 182-195. https://doi.org/10.1016/j.cose.2014.10.007

Saks, M. (2012). Defining a Profession: The Role of Knowledge and Expertise. Professions and Professionalism, 2(1), 1-10.

Sherry, M., Carcary, M., McLaughlin, S., \& O’Brien, C. (2013). Actions towards Maturing the ICT Profession in Europe. International Journal of Human Capital and Information Technology Professionals (IJHCITP), 4(1), 46-61. https://doi.org/10.4018/jhcitp.2013010105

Sherry, X. (2013). National strategy for digital records: Comparing the approaches of Canada and China. International Journal of Information Management, 33(4), 697-701. https://doi.org/10.1016/j.ijinfomgt.2013.02.004

Thornley, C., Ferguson, S., Weckert, J., \& Gibb, F. (2011). Do RFIDs (radio frequency identifier devices) provide new ethical dilemmas for librarians and information professionals? International Journal of Information Management, 31(6), 546-555. https://doi.org/10.1016/j.ijinfomgt.2011.02.006

Thornley, C., Murnane, S., McLaughlin, S., Carcary, M., Doherty, E., and Veling, L. 2018. International Journal of Human Capital and Information Technology Professionals (IJHCITP). 2018 9(4) :56-71. 
Thornley, C., Murnane, S., Veling, L., McLaughlin, S., Carcary, M., \& Doherty, E. (2016). Professional identity and ethical engagement in the international ICT community. Presented at the Irish Academy of Management Conference.

van der Linden, N. (2017). Digital Organisational Frameworks and IT Professionalism. The European Commission. Retrieved from http://ictprofessionalism.eu/

van der Linden, N., Siebes, C., Bonazzoli, F., Dimauro, M., Catteneo, G., \& Kolding, M. (2017). Development and Implementation of a European Framework for IT Professionalism (Capgemini Consulting, Ernst \& Young, and IDC. No. EASME/COSME/2014/012). European Commission.

Walsham, G. (1993). Interpreting Information Systems in Organizations. Chichester ; New York: John Wiley \& Sons. Retrieved from https://doi.org/10.1177/017084069401500614

Weckert, J., \& Lucas, R. (2013). Professionalism in the Information and Communication $\begin{array}{lllll}\text { Technology Industry. ANU Press. Retrieved } & \end{array}$ http://press.anu.edu.au/publications/series/centre-applied-philosophy-and-publicethics-cappe/professionalism-information

Weiss, J. (2017). Ethics and CSR Research in Top Ranked IS Journals, 1980-2013: A Developing Trend or Anomaly? Presented at the Hawaii International Conference on System Sciences, Honolulu, Hawaii. https://doi.org/10.24251/HICSS.2017.694

Zompras, A., \& Siakas, K. (2015). An Investigation of ISO 26000 and Social Responsibility Practices Applied in IT Companies. International Journal of Human Capital and Information Technology Professionals (IJHCITP), 6(2), 33-48. https://doi.org/10.4018/IJHCITP.2015040103

Thornley, C., Murnane, S., McLaughlin, S., Carcary, M., Doherty, E., and Veling, L. 2018. International Journal of Human Capital and Information Technology Professionals (IJHCITP). 2018 9(4) :56-71. 